MoRris, E. J. (1956). J. gen. Microbiol. 15, 629-631

\title{
A Selective Medium for Brucella spp.
}

\author{
By E. J. MORRIS \\ Microbiological Research Establishment, Ministry of Supply, Porton, Wiltshire
}

SUMMARY: A selective medium tor Brucella spp. is described which contains 5-nitrofurfurylmethyl ether, bacitracin, polymyxin and Actidione. Organisms normally encountered in culture from faeces or soil are completely suppressed on the medium while brucellas grow quantitatively within $65 \mathrm{hr}$. of incubation.

A selective medium is essential when the detection of brucellas by direct culture is required from such material as milk, soil, faeces, etc. Felsenfeld et al. (1951) devised a medium containing circulin, polymyxin, bacitracin and sulphadiazine to isolate brucellas from chicken faeces. Kuzdas \& Morse (1953), using a similar medium, found that 5 days of incubation were necessary to grow these organisms from soil suspensions. Mair (1955) used polymyxin, penicillin and Gentian violet to detect Brucella abortus from herd samples of milk, but reported that the medium was sometimes overgrown by contaminant organisms.

The high antibacterial activity of nitrofuran compounds has been reported by many workers (e.g. Dodd \& Stillman, 1944; Paul \& Bender, 1950; Dodd, Cramer \& Ward, 1950). In the present study it was found that 5-nitrofurfurylmethyl ether incorporated in nutrient agar allowed the quantitative growth of Brucella spp., while it inhibited the growth of the majority of other Gramnegative organisms, including Proteus spp. The medium finally devised enables brucellas to be diagnosed within a $65 \mathrm{hr}$. incubation period by direct cultivation from material heavily contaminated with other bacteria.

\section{METHODS}

Media. The growth of the brucellas was compared on several basal media, e.g. Difco tryptose agar, Albimi agar, 'Oxoid' nutrient agar and a modified Hartley digest agar (TMA) used in this department. Tryptose agar and TMA were identical in their ability to support growth of brucellas in higher concentrations of the inhibitory constituents of the medium than the other basal media tested. The selective medium finally devised consisted of TMA or Tryptose agar at $\mathrm{pH} \mathbf{7 \cdot 4}$ with $\mathbf{1 / 3 0 , 0 0 0}(\mathrm{v} / \mathrm{v})$ 5-nitrofurfurylmethyl ether ('Furaspor'; Menley and James Ltd.); 25 units bacitracin/ml.; 4 units polymyxin B ('Aerosporin'; Burroughs Wellcome and Co.)/ml. and 1/10,000 (w/v) Actidione (The Upjohn Co. U.S.A.). The additions were made to the melted agar cooled to $50^{\circ}$ and poured into Petri plates in $20 \mathrm{ml}$. amounts. The agar plates were dried for $2 \mathrm{hr}$. at $37^{\circ}$ to remove surface moisture and could be stored at $4^{\circ}$ for at least 4 weeks without loss in selective properties. The medium was equally selective when bacitracin was replaced by licheniformin. 
5-Nitrofurfurylmethyl ether is a viscous yellow liquid soluble at 1/500 in water at room temperature. It is heat labile and completely inactivated by autoclaving at $120^{\circ}$. A $1 / 500$ aqueous solution remains active after several months of storage in the dark at $4^{\circ}$.

Growth tests. The Miles \& Misra (1938) technique was used to inoculate the control and test media with pure cultures of brucellas and common contaminating organisms. Inocula were adjusted to give $c .200$ colonies of brucellas/plate and $\mathbf{2 0 0 0}$ of other organisms per plate. Brucella spp. were also add $\mathrm{d}$ to suspensions in water of soil $(1 \mathrm{~g} . / 20 \mathrm{ml}$.) and faeces $(1 \mathrm{~g} . / 100 \mathrm{ml}$.) so that $0 \cdot 1 \mathrm{ml}$. when plated on the media would yield $c .100$ brucella colonies. Tryptose agar and TMA were used as control media. Incubation for all tests was at $37^{\circ}$ for $65 \mathrm{hr}$. in air and in air $+10 \%(\mathrm{v} / \mathrm{v}) \mathrm{CO}_{2}$.

\section{RESULTS}

Growth of pure cultures. The 19 strains of the genus Brucella examined (Brucella suis (6), B. abortus (8), B. melitensis (3) and two intermediate strains) all gave similar counts on the selective nitrofuran medium and control agar. The results of a typical experiment are summarized in Table 1. Colonies were

Table 1. Colony counts of Brucella species on the nitrofuran selective medium and on control nutrient agar

\begin{tabular}{|c|c|c|c|}
\hline \multirow{3}{*}{$\begin{array}{c}\text { Species } \\
\text { Brucella suis }\end{array}$} & \multirow[b]{3}{*}{ PS3 } & $\begin{array}{c}\text { Nitrofuran } \\
\text { medium } \\
\text { (Color }\end{array}$ & $\begin{array}{l}\text { Control } \\
\text { agar } \\
\text { ate) }\end{array}$ \\
\hline & & & \\
\hline & & 290 & 289 \\
\hline & $\mathrm{K} / \mathrm{n}$ & 198 & 191 \\
\hline & $\mathbf{S} / \mathbf{R}$ & 269 & 275 \\
\hline & 37 & 145 & 158 \\
\hline & В 64 & 204 & 208 \\
\hline & $\mathbf{B 6 7}$ & 181 & 221 \\
\hline \multirow[t]{3}{*}{ B. melitensis } & MM 6015 & 212 & 226 \\
\hline & & 141 & 156 \\
\hline & В 1020 & 165 & 178 \\
\hline \multirow[t]{8}{*}{ B. abortus } & 29 & 221 & 198 \\
\hline & B31 & 168 & 157 \\
\hline & B 34 & 182 & 186 \\
\hline & B41 & 135 & 136 \\
\hline & B 47 & 214 & 225 \\
\hline & B 127 & 236 & 221 \\
\hline & В 1019 & 222 & 243 \\
\hline & $\mathrm{S} 19$ & 103 & 122 \\
\hline \multirow{2}{*}{ Intermediate } & B55 & 142 & 154 \\
\hline & В 206 & 180 & 175 \\
\hline
\end{tabular}

smaller $(0 \cdot 8-1 \cdot 0 \mathrm{~mm}$. diam.) on the selective medium than on control agar $(1.2 \mathrm{~mm}$. diam.) but were otherwise typical in appearance (Fig. 1). B. suis and $B$. melitensis grew equally as well when incubated in air or in the air $+\mathrm{CO}_{2}$ mixture. Slide-agglutination tests were normal with colonies grown on the selective medium. 

Journal of General Microbiology, Vol. 15, No. :3
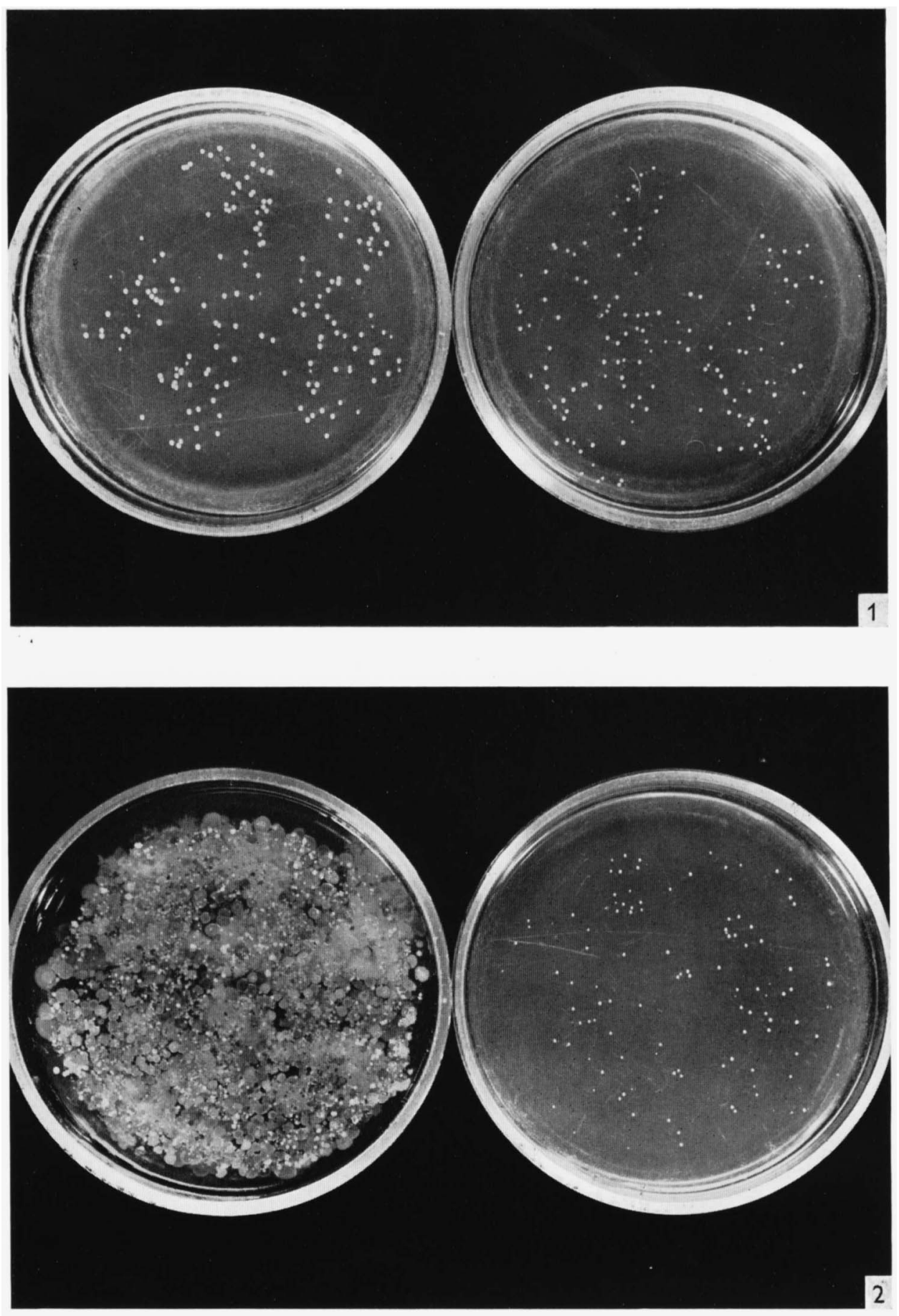

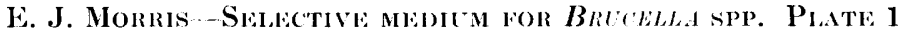


Growth of the following organisms (showing in parentheses the number of strains tested) was completely inhibited on the selective medium: Proteus vulgaris (3), Escherichia coli (4), Aerobacter aerogenes (2), Alcaligenes faecalis (6), Streptococcus faecalis (1), Micrococcus tetragenus (5), Staphylococcus aureus (3), Pseudomonas aeruginosa (1), Serratia marcescens (2), Bacillus spp. (20), Salmonella spp. (6), Achromobacter spp. (6).

Tests with soil and faecal suspensions. In most instances Brucella spp. were grown in pure culture on the selective medium from the many soil suspension mixtures tested. Growth of contaminant organisms in each case was confluent on control agar. Colonies which sometimes developed on the medium were mainly Achromobacter species; their numbers (2-20/plate) did not interfere with diagnosis of brucellas. Brucella spp. were also isolated without difficulty from the artificially infected suspensions of guinea-pig faeces (Fig. 2). On rare occasions, however, contaminant colonies encountered on the medium from faecal suspensions were unusually high (200/plate). The majority of these colonies were Alcaligenes spp. and were suppressed when the medium was incubated in an atmosphere of air $+10 \%(\mathrm{v} / \mathrm{v}) \mathrm{CO}_{2}$, while growth of $B$. suis and B. melitensis was unaffected by these conditions.

I am indebted to Dr J. A. Olsen of Eaton Laboratories and Dr M. L. Graeme of Menley and James Ltd. for generous gifts of nitrofuran compounds and to Mr L. H. Kent and Dr B. T. Tozer for a supply of licheniformin. Thanks are also due to Professor J. C. Cruickshank and Dr J. E. Smith for brucella cultures and to Mr C. M. R. Pitman for technical assistance.

\section{REFERENCES}

Dodd, M. C. \& Stilluman, W. B. (1944). Bacteriostatic action in vitro of some simple furan derivatives. J. Pharmacol. 82, 11.

Dodd, M. C., Cramer, D. L. \& WArd, W. C. (1950). The relationship of structure and antibacterial activity in the nitrofurans. J. Amer. pharm. Ass. 39, 313.

Felsenfeld, O., Young, V. M., Loeffler, E., Ishihara, Sachiko, J. \& Schroeder, W. F. (1951). A study of the nature of brucellosis in chickens. Amer. J. vet. Res. $12,48$.

Kuzdas, C. D. \& Morse, E. V. (1953). A selective medium for the isolation of brucellae from contaminated materials. J. Bact. 66, 502.

MAIr, N. S. (1955). A selective medium for the isolation of Brucella abortus from herd samples of milk. Mon. Bull. Minist. Hlth Lab. Sero. 14, 184.

Miles, A. A. \& Mrsra, S. S. (1938). The estimation of the bactericidal power of the blood. J. Hyg., Camb. 38, 732.

Paul, H. E. \& Bender, R. C. (1950). Urinary antibacterial activity following oral administration of nitrofurans. J. Pharmacol. 98, 153.

\section{EXPLANATION OF PLATE}

Fig. 1. Left: colonies of Brucella suis on Tryptose agar after $65 \mathrm{hr}$. incubation at $37^{\circ}$ in air. Right: the same inoculum on the selective nitrofuran medium.

Fig. 2. Left: growth from $0 \cdot 1 \mathrm{ml}$. of a faecal suspension on Tryptose agar after $65 \mathrm{hr}$. incubation at $37^{\circ}$ in air. Right: the same inoculum on the selective nitrofuran medium showing a pure growth of Brucella suis.

(Received 12 June 1956) 